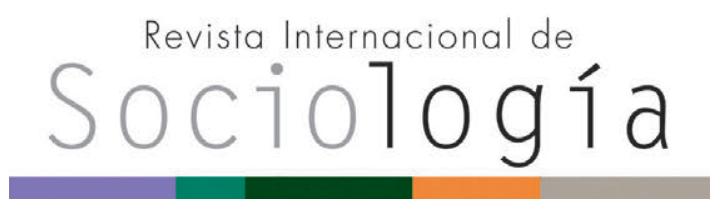

Revista Internacional de Sociología RIS vol. 74 (4), e048, octubre-diciembre, 2016, ISSN-L:0034-9712 doi: http://dx.doi.org/10.3989/ris.2016.74.4.048

\section{FROM THE STREET TO INSTITUTIONS THROUGH THE APP: Digitally Enabled Political Outcomes of the Spanish Indignados Movement}

\author{
EDUARDO ROMANOS \\ Universidad Complutense de Madrid \\ eromanos@ucm.es \\ IGOR SÁDABA \\ Universidad Complutense de Madrid \\ igor.sadaba@cps.ucm.es
}

Cómo citar este artículo / Citation: Romanos, E. and I. Sádaba. 2016. "From the Street to Institutions through the App: Digitally Enabled Political Outcomes of the Spanish Indignados Movement". Revista Internacional de Sociología 74 (4): e048. doi: http://dx.doi.org/10.3989/ris.2016.74.4.048

\section{ABstract}

This article examines the relationship between social movements' digital democratic innovations and political parties through a case study based on the involvement of $15 \mathrm{M}$ activists in the creation and development of new political parties in Spain. By analyzing the impact of certain technological activist groups on the implementation of the movement's demands in terms of mechanisms of participation and deliberation in the new parties through the use of digital technologies, we aim to evaluate the activists' contribution to the transformation of formal politics and the deepening of democracy. In this sense, we explore the role of so-called 'tech activists' as mediators of political participation, and the digital repertoire of action they use. Sources used include various documents and websites as well as interviews with key informants and notes from participant observation in meetings and assemblies.
\end{abstract}

\footnotetext{
KeyWORDS

Democratic Innovations; ICT; Political Participation; Political Parties; Protest Movements.
}

\section{DE LA CALLE A LAS INSTITUCIONES A TRAVÉS DE LAS APPS: Consecuencias políticas de las prácticas digitales en el $15 \mathrm{M}$}

Copyright: (c) 2016 CSIC. This is an open-access article distributed under the terms of the Creative Commons Attribution License (CC BY) Spain 3.0.

Received: 20/12/2015. Accepted: 01/07/2016. Published on line: 21/10/2016

\section{RESUMEN}

Este artículo analiza las innovaciones democráticas provenientes del campo de los movimientos sociales y su relación con los partidos políticos a partir de un caso de estudio centrado en la participación de activistas del $15 \mathrm{M}$ en la creación y el desarrollo de nuevos partidos políticos en España. Nuestra intención es evaluar la aportación de los activistas a la transformación de la política formal y la profundización de la democracia a través del análisis del impacto de determinados grupos en la implementación de las demandas del movimiento en forma de mecanismos digitales de participación y deliberación en los nuevos partidos. En este sentido, el artículo explora el papel de los llamados 'activistas tecnológicos' como mediadores de la participación política y el repertorio digital de acción empleado por ellos. Las fuentes analizadas incluyen diversos documentos y páginas web, entrevistas a informantes clave y la observación participante de reuniones y asambleas.

\section{Palabras Clave}

Innovaciones Democráticas; Movimientos de Protesta; Participación Política; Partidos Políticos; Tecnologías de la Información y la Comunicación. 
Social movements and democratization processes influence one another. On the one hand, "democratization in itself promotes formation and proliferation of social movements" (Tilly 2004: 137). On the other hand, as pointed out by Talpin (2015), social movements foster the democratization of society by introducing participation mechanisms and the creation of new political institutions. Thus, the relationship between social movements and the phenomena of 'democratic deepening' is an important issue in the study of collective action, and it deserves in-depth scrutiny (della Porta 2014). This article evaluates the impact of social movements in the contemporary democratic system by analyzing recent democratic innovations implemented by Spanish institutions as a response to the mobilization of the so-called indignados, or $15 \mathrm{M}$ movement, which emerged in Spain in May 2011. By "democratic innovations," we refer to new practices that are being tested in order to promote participation and democratic deliberation. More specifically, this article enquires into the role played by technological activists in the adoption of these innovations by new parties and institutions (city councils) emerging after the protest cycle.

The Internet has multiplied the ways of influencing public opinion and policymaking, and at the same time has given civil society unheard-of possibilities for coordination and mobilization (Calderaro and Kavada 2013; Earl and Kimport 2011). Social movement scholars have been active in the analysis of the impact of new technologies on organized civil action and social movements. Many of these studies focus on online participation (Anduiza et al. 2010), on the redefinition of typologies of participation/commitment (Ekman and Amnå 2009), and on theoretical debates about the efficacy of "digital mobilization" (Bennett et al. 2008; 2011). Some areas, however, have received little attention to date, such as the role played by new technologies in the institutionalization of social movements. This article examines the relationship between social movements and political parties through a case study based on the involvement of $15 \mathrm{M}$ activists in the creation and development of new political parties in Spain. By analyzing the impact of certain activist groups on the implementation of the movement's demands in terms of mechanisms of participation and deliberation in the new parties and institutions through the use of digital technologies, we aim to evaluate the activists' contribution to the transformation of formal politics and the deepening of democracy. In this sense, we explore the role of so-called 'grassroots tech activists' (Hintz and Milan 2009) as mediators of political participation, and the digital repertoire of action they use to develop democratic innovations. What role do technological activists play in transmitting the democratic demands of social movements? How much do they intervene in the institutional implementation of democratic innovations? The answers to these questions can help us to situate the Spanish example in a wider context. Our hypothesis is that the involvement of this kind of activist in Spanish political parties may reduce the distance between a discourse which stresses the democratic potential of new technologies and the real impact of these technologies on social change, as observed in other recently-created European parties which have, in principle, a similar outlook on ICT (Treré and Barassi 2015). In order to achieve this aim, we will analyze the impact of tech activism in new movement-parties with different scope and nature: a national-wide traditional party (Podemos) and several electoral coalitions at the local level (Ahora Madrid, Barcelona en Comú, Zaragoza en Común).

\section{SOCIAL MOVEMENTS AND DEMOCRATIZATION}

One of the top (if not the main) goals of social movements has been to develop new concepts of democracy (della Porta and Diani 2006: 239). Activists have participated in the creation of open public fora in which to experiment with alternative democratic models. The new social movements that emerged, largely in Europe, in the 1970s and 1980s, revivified and updated a concept of direct democracy that, to some extent, originated in the Anarchist tradition. Direct democracy of assemblies and councils emerged as an alternative to the liberal concept of democracy and to Socialist- or Catholic-inspired organized democracy (Kitschelt 1986; 1993). The following transnational wave of protest led, at the turn of the millennium, by the movement for global justice, practiced a new concept of deliberative democracy: an "organizational culture" based on diversity, subjectivity, transparency, constructive open confrontation aimed at the construction of common grounds, and "ideological contamination" beyond dogmatism (della Porta 2005a; 2005b). ${ }^{1}$

Throughout history, political institutions - not without delays, complications and setbacks - have adopted new mechanisms of participation, deliberation and decision-making, partially in response to the demands posed by social movements (Kriesi and Wisler 1999; Polletta 2002; Smith 2009; Talpin 2015). The participative budget passed in the Brazilian city of Porto Alegre in the late 1980s is a clear example of this. The local government designed the budget in accordance with the demands posed by civil society through neighborhood associations. Over time, this innovation expanded to other cities in Brazil and elsewhere (Sintomer, Herbeg and Röcke 2008; Ganuza and Baiocchi 2012). Participative budgets are a common participative mechanism worldwide, including in some Spanish cities. Porto Alegre also became a symbol of a new movement for global justice in 2001 , with the celebration of the first edition of the World Social Forum, which was promoted by several civil society groups and organizations. The meeting was sponsored by the local government, held by the 
Workers' Party. Porto Alegre was also the seat of the second and third editions, after which the forum started traveling to other cities.

In a way, the participative innovations that are currently making their way into Spanish institutions (see below for examples), have been "cooking" for some time. They were already present in previous waves of mobilization, but did not fully crystallize until the recent protest cycle. The post-2010 transnational protest wave has significant continuities with alter-globalization movements (Romanos 2013; Flesher Fominaya 2014a). In their protests and networks, the indignados show a strong commitment with the model of empowered deliberative democracy practiced by the alterglobalization movement, which they updated with a relatively novel concept of organizational inclusiveness directed at potential participants and the transformation of public spaces into open, empathic arenas (Romanos 2016). They brought practices of deliberative democracy out into public squares (Corsin and Estalella 2011), where passers-by were invited to join in. This implies a change in movement orientation towards the ordinary people outside the gatherings rather than on the activities of those internal to these. The indignados strove to build a movement of 'anyone' based on an extremely inclusive 'we' that aimed to go beyond ideological or partisan affiliations and the auto-referential dynamics, organizational forms, discourses, and identities of traditional social movements.

Spanish indignados furnish their democratic practices with a "well-founded critique of traditional leadership and representative forms of political action" (Espinoza Pino 2013: 230) in a context of grave economic and political crisis. The following section will introduce the sociopolitical context, especially concerning the criticisms and democratic demands posed by the indignados, the (lack of) response of institutions, and the eventual emergence of electoral alternatives with the creation of new political parties. We shall then discuss the participative and democratic innovations introduced by some digital practices and the role of grassroots technological activists as disseminators or links between social movements and political parties. This will be followed by the analysis of experiences and interpretations as expressed in a series of in-depth interviews with several technological activists who participated in the Spanish 15M and, subsequently, in the creation and development of new political parties. As a result, we shall indicate important factors in the transition of democratic innovations from social movements to political parties.

\section{ECONOMIC CRISIS, DEMOCRATIC DEFICIT AND PARTICIPATIVE INNOVATIONS}

Although democratic innovations result from successive mobilization cycles, these proliferate in periods when the legitimacy of the system of government comes under question (Kriesi and Wisler 1999; Talpin
2015). It is for this reason that they cannot proliferate unless certain conditions prevail. In the context of the Great Recession, the Spanish population regarded political responses as inadequate (della Porta et al. 2016). A large proportion of the Spanish population also perceived the democratic system as deficient, and these people demanded a (new) political system in which citizens could become more involved in decision-making processes (Font et al. 2012; Font and Alarcón 2012). Even more than the economic crisis, the many cases of corruption and the deficits of the democratic system seem to be the main motives for participation in the indignados movement (Redes, Movimientos y Tecnopolítica 2014; cf. Likki 2012).

Unlike previous protests, in which the quality of the democratic system was not such a prominent issue, participants in the new movement have underlined the need for more, and more efficient, political participation and deliberation channels. Perhaps for this reason, organizational and participative innovations proposed by the indignados went beyond expectations and have been accepted by the institutions more easily than predicted. Their demands were also related to the degree of control that the economic structures exercise over political decision-making (as for example, in the motto "there is no democracy if the markets rule over us"). The activists have identified austerity policies with the absence of democracy (and sovereignty). In addition, corruption (the main concern among Spanish citizens, according to the Centro de Investigaciones Sociológicas' opinion polls) is regarded as the product of a democratic system whose control mechanisms are weak, and of a political system that has encouraged the enrichment of some politicians to the detriment of the living conditions of the majority. Slogans such as "they don't represent us" or "they call it a democracy, but it isn't" were used to criticize the democratic model established during the Transition, which was then perceived as a "low-intensity democracy" (Arribas 2015): a system whereby elites fight to safeguard the privileged position of the main political parties and trade unions while limiting the participation channels of civil society.

As with anti-austerity contention in Latin America (Roberts 2014), consensus among the major parties with respect to the neoliberal reforms implemented during the crisis found strong criticism in the streets in the Spanish case. ${ }^{2}$ The indignados sustained a strong critique of these parties and the party system "which supported austerity measures and has not taken care of citizen needs in the wake of the crisis, instead using public money to socialize private banking debt" (Flesher Fominaya 2014b). The 1978 Constitution embodied a representative government model based on a two-party system, political alternation, a decentralized territorial structure, and an electoral system that favored the formation of parliamentary majorities and strong and stable 
governments (Gunther, Montero and Botella 2004; Laiz 2002). This institutional design gave precedence to the executive power over the legislative, and imposed severe limitations on direct democracy mechanisms (Jiménez 2007). In fact, "Policy priorities were mainly defined by the prime minister's inner core [while] weak parliamentarianism inhibited the development of regular and institutionalized links between parties and [organized] civil society, weakening, in the long term, both parties and voluntary associations" (Fernandes 2014: 15). The political elites designed an institutional framework that isolated representatives from the direct social pressure of protest movements in a political context of social effervescence, the atomization of parties, and strong resistance from the right and the army to the moves that were being made to leave Franco's dictatorship behind. Moreover, Spanish authorities pay little or no attention to street protests, ignoring the numbers and concerns of protesters. This applies to both conservative and progressive political parties, and the same attitude is projected through mass media (Fishman 2011; Sampedro 1997; Asens 2004).

Roberts (2014) shows that in Latin American countries "where center-left or labor-based populist parties played a major role in the process of structural adjustment ... a sequel of explosive social protest that directly or indirectly toppled presidents, led to partial or complete party system breakdowns, and [in some cases] ushered in the election of an anti-system populist figure or a new movement party of the left". In Spain, where a center-left party "voluntarily" initiated the implementation of neoliberal policies (i.e., under the pressure of supranational European institutions) in the context of financial crisis, the contentious cycle has so far been partially similar. The decline in the protest cycle has coincided with the emergence of new political parties which are, in one way or another, related to the 15M (Jerez, D'Antonio and Maestu 2015; Lobera 2015; Marzolf and Ganuza 2016). The best known of these is Podemos (We Can), which in May 2014, only three months after its foundation, had an unprecedented electoral success: it attracted 1.2 million votes and gained five MPs in the elections for the European Parliament. Essentially, the party leaders seized the opportunity presented by the structural changes resulting from the economic and political crisis and created their own political party. The party has reacted to the emotions of the public in order to transform the wave of indignation connected with the $15 \mathrm{M}$ movement into excitement for political change via the electoral process.

Elections affect social movements in many different ways, also by altering the opportunity structure (Heaney 2013). As elections draw nearer, activists show an increasing tendency to resort to the electoral mechanism to channel their demands (Blee and Currier 2006). In this regard, the $15 \mathrm{M}$ movement has followed the pattern. The $15 \mathrm{M}$ emerged a week before the 2011 local and regional elections. Four years later, many activists have regarded the new electoral cycle (local and regional elections in May 2015, and general elections in December of the same year) as the opening of a window of opportunity which may counterbalance the lack of political response prompted by the previous protest cycle. This comes on top of the effects of the 2014 European elections and their surprising outcome for Podemos, which seems to have affected the activists' perception of the possibilities of accessing political power through institutional channels that are already in place.

After building a strong critique of the dominant concept of democracy, and experimenting with novel concepts of democracy in the streets, the incipient institutionalization of the movement in a number of new political parties (Podemos, Ganemos, Partido X, etc.) marked the start of a new phase in the development of the notion of democracy within the protest cycle. This institutionalization is somewhat surprising, given the activists' poor opinion of traditional political parties and, in general, the current system of political representation. In this regard, one of the results of the 2011 protests appears to have been the emergence of new ways of articulating the relationship between social movements and political parties. In some ways, we are now presented with a movement-party within which the evolution of one form of collective action into another may be observed. The new technologies seemed to have played a significant role in this evolution (Jerez, D'Antonio and Maestu 2015). The extensive use of digital tools, which encourage participation and deliberation in the creation and development of these new parties, in some ways reproduced essential values and practices of the movement, thus facilitating the identification between the 15M activists and the parties. The use of these digital tools has been accompanied by the development of a certain technophilic frame that stresses the potential of new technologies for democratic deepening. The frame developed by post-15M parties illustrates a new concept of representation. The classic, delegated political representation is abandoned in favor of a distributed representation model (decentralized networks are used as a vehicle for the representation of the citizens). Deliberative and distributed representation models, which the Internet has made possible, are like horizontal, assembly based schemes in which the process of consultation is permanent - a sort of constant referendum (Gimmler 2001). A technological imaginary, according to which digital networks are regarded as invisible hands working to put together different opinions in a coherent and efficient manner, is therefore essential. We could even say that decentralized digital networks "simulate" a real democracy; this is indeed the opinion of activists, who regard this simulacrum as a political experiment with real value (Romanos and Sádaba 2015). 


\section{Digital PARTICIPATION AND TECH-ACtIVISTS}

The penetration of the internet and digital technologies has redefined many of the classical political participation models. Some of the most innovative recent forms of collective action derived from the use of online communication tools (Vissers and Stolle 2013). Beyond the question concerning the actual degree of engagement that these mechanisms imply, digital media have created new action repertoires and ground-breaking intervention models (Van Laer and Van Aelst 2008). Some of these could directly qualify as democratic innovations, as they have played an unprecedented role in fostering deliberative democratic processes, debate, interaction and decision-making. The Internet has proven to be the natural environment of traditional collective action mechanisms (signature collection, donations, debate, decision-making, collaborative writing, etc.), the potential of which is thus realized. Van Laer and Van Aelst (2008: 1149) have typified these actions, including concepts such as culture jamming, protest website/alternative media, email bomb/virtual sit-ins, online petitions, monetary donations, consumer behavior, hacktivism, etc., and have pointed out that these activities cannot expand indefinitely.

The focus of this article is the issue of how these activities move from social movements to institutions, and to political parties. In a way, we might say that some of the participative mechanisms and action repertoires that pertain to social movements enter, as democratic innovations, the area of conventional politics. New political parties, and to some extent the institutions - local and national - have adapted and assumed some of the demands posed, and the methods developed, by social movements (Buss, Redburn and Guo 2007). All direct, deliberative or digital democratic processes developed as a followup from the social movement to the political party can therefore be understood in this light (Newton and Geissel 2011).

Specifically, the internet is particularly well suited for experimentation with distributed, anonymous, horizontal and massive forms of interaction and communication. The web has thus become the ideal arena for testing deliberative democracy models (Witschge 2004). Digital networks, understood as a new form of public forum, can compensate for the shortcomings of traditional representative democracy (Dahlberg and Shiapera 2007). Some online deliberative practices (discussion, debate, polls, collaborative filtering of proposals, etc.), when they are binding, become processes of radical democracy.

At any rate, some of these online communication channels were not taken up by the public spontaneously, but became popular as a result of the work of grassroots tech-activists (Hintz and Milan 2009). In our opinion, these tech-activists also played a crucial role in the transference of some of the digital democratic innovations related to $15 \mathrm{M}$ to the political parties and institutions. In recent times, hackers and other activists with expertise in digital media have gone a long way in realizing the potential of computer networks in fostering social and political change. This article focuses on the role played by tech activists in the diffusion of democratic innovations and their brokerage between social movements and political parties, in this case, between the $15 \mathrm{M}$ movement and the emerging parties and city councils. In our view, they have played an important role in connecting these different phenomena and in disseminating and implementing certain digital participation mechanisms. It has been discovered that many of the political experiments in deep democracy were supported by a relevant social group which lobbied, disseminated and activated these democratic proposals (Buss, Redburn and Guo 2007). This article will concentrate on the role played by certain experts in technological activism (Mora 2014) and how they have contributed to prolonging the effects of the mobilization cycle through the new political parties (Podemos, "council platforms" 3 ) and the implementation of new online experiments in deliberative democracy. Chi et al. (2010) have pointed out some keys to understanding "technology-mediated social participation" (TMSP), such as the context of social or political participation, the role of people as social agents, and the participationenabling tools. This article will develop other analytical dimensions concerning the process of transference of democratic innovations from post-15M collective action to political parties and institutions.

\section{Methodology and empirical anAlysis}

The methodology of this article was specifically designed to illustrate empirically and verify the aforementioned working hypothesis. The investigation has been chiefly qualitative in nature (Denzin and Lincon 2005), including the review of relevant bibliography and other sources (manifestos, writings, news, interviews, statements) concerning the social movements and the political parties under scrutiny. This allowed for the definition of the hypothesis and its theoretical framework.

This is followed by a series of in-depth, semistructured interviews with different persons involved in groups of communication and participation or techactivism (Brinkmann and Kvale 2014). In order to meet qualitative structural sampling criteria, we have attempted to cover all relevant discursive spaces by taking several variables into account. Firstly, we tried to interview members of a number of political parties (Podemos, Ahora Madrid/Plataformas municipalistas and Partido $\mathrm{X}$ ), and secondly, people with different technical skills and different participation profiles (some were more closely involved in social activism and others in political parties). It must be noticed that 
most of the tech-activists have participated in more than one post-15M political party (and some are even currently working at city councils). Participants were not differentiated on the basis of age or gender, as these were deemed to be non-relevant variables for the issue in hand. Owing to this structural and qualitative empirical design, sample saturation is fulfilled and guaranteed (Mason 2010). Twelve interviews were carried out in total, in Madrid and Barcelona, between October 2014 and January 2016. In order to avoid repetition, we have selected the most representative extracts from a few of the interviews.

Finally, this was complemented with our participation in six sessions of ethnography and participant observation (between September and December 2015) of BetaDemic, which is an analysis and study group composed by different experts and activists, including grassroots tech activists. This group was formed after the launch of a deliberative portal MadridDecide by the Madrid City Council (governed by Ahora Madrid). ${ }^{4}$ Our presence at these meetings and the open session celebrated in Medialab in December 2015 supplemented, and contributed to shaping our interpretation of, the data collected previously. ${ }^{5}$ The field notes helped us to design and analyze the in-depth interviews.

\section{THE DISCOURSE(s) OF DEMOCRATIC INNOVATION}

The transcription of the interviews was subject to critical discourse analysis (Wodak and Meyer 2009) in order to reveal the meanings shared by tech-activists. We were particularly interested in establishing the imaginaries and discourses that give meaning to their position with regard to the democratic innovations proposed and the forms of participation that link social movements and institutions. The interviews aimed to reveal how the democratic innovations pressed from $15 \mathrm{M}$ have been assimilated by the institutional establishment and how they interact with collective action. We have categorized these discourses under five headings, which allows for the analytical interpretation of similarities and differences concerning: the status of these activists with regard to the party; the extension, the timing and the control of democratic innovations; and the frames regarding their implementation.

Status: The interviewees present a different level of engagement with their party of reference. Some of them define themselves as external and circumstantial collaborators, while others have entered the institutions as members of the parties. This links with the distinction between "manifest participation" and "latent participation" (Ekman and Amnå 2009). The position of the tech-activists with regard to their parties determines, to an extent, the scale of their impact. The external/internal positions of activists were often referred to during the interviews, with expressions such as "external collaborator" or "satellite":
"I am but a satellite ... we started using tools in order to foster participation processes ... and that's where I took a bit of a more active role." (Interview, Ahora Madrid)

“In Ahora Madrid we don't do much as a group, other than going to meetings and talking about our experience with the tools that we've been using to date." (Interview, Podemos/Ahora Madrid)

Yet, these outside/inside positions also reflect the self-regard of the tech-activist as a link between different groups. The idea of the hacker as broker (or "civic hackers" [Townsend 2013]) is particularly important for a full understanding of recent democratic innovations, as these activists have played a basic role as connectors and facilitators between different groups, collectives and trends. To an extent, they have been the key variable in the institutional development of democratic innovations. They not only use these tools very actively, but have a catalyzing effect in mobilizing others to do so (Talpin 2015). The tech activists under review here play this role: they invite others to evaluate digital tools and suggest ways to improve them, facilitating participation towards democratic innovations. Their status within their parties of reference can therefore go from that of an external collaborator ("reserve structures" [Tarrow 2011: 240]) to that of full membership:

\footnotetext{
"My role has been to wipe fears away, to create a pad or set up streaming, as tech-activist, promoter and motivator. Give them what they need, the tool. A facilitator. We have also been mediators between different generations, with different levels of computer literacy. I see myself as a disseminator, not only of collaborative technology, but of a collaborative culture. I don't think we'd have got so far without that" (Interview, Partido X/Zaragoza en Común)

"We wanted to be middlemen between developers and needs in political spaces, in participation spaces for many groups related to 15M" (Interview, Podemos/Ahora Madrid)

"The tech-activists are not the important thing; the important thing is the internet, and there the tech-activists have a very important role to play. They are not more committed than others; it is just that they know the tools better" (Interview, Podemos/Ahora Madrid city council)
}

Control/Institutionalism: Although digital participation is part of all 15M-related parties, not all of them use it in the same way. Specifically, in some cases these democratic innovations have been incorporated into conventional politics as an institutionalized tool, while in others the tools emanate directly from the citizen-base and escape the control of political parties. ${ }^{6}$ These parties emerged from horizontal, assembly based movements, and thus the arrival of online participation tools in the area occupied by political parties generates tensions, which each of these parties have solved in their own way (Heaney and Rojas 2015 demon- 
strate this with regards to the relationship between the anti-war movement and the Democratic Party). In order to explain the assimilation of participative mechanisms, activists do not insist so much on the outside/inside theme as on the up/down idea ("The ascent to the institutions led by Podemos is from the top down, and I prefer one that goes from the bottom up" [Interview, Ahora Madrid]).

More specifically, the interviews reveal a clear division about where these democratic innovations fit. While some think that they should follow the norms and decisions taken by the political parties (that is, the central party committees and assemblies), others think that, as they are a tool in the hands of the citizens (even if they are not members of the party), they must be the ones to set the rules.

\begin{abstract}
"Podemos wanted to exercise some control over the process, to supervise closely where the process was heading to, while Ganemos wanted to exploit the possibilities more fully ... That was a point of contention. Ganemos accepts political parties, but only if the citizens have a voice within them." (Interview, Ahora Madrid)
\end{abstract}

"At the start working with Podemos was quite improvised; whatever we suggested they'd reply 'yes, go for it', we had total freedom of action ... We reached an agreement in Labodemo, ${ }^{7}$ which was later run past the Citizen Council, ${ }^{8}$ and sometimes this meant that not everything was approved, which was the cause of some friction ... whenever we wanted to do something that did not agree with the strategy of Podemos." (Interview, Podemos/Ahora Madrid)

"At the beginning [in the Participation Area of Podemos] it was great, because everything was starting. It was all green pastures with no barriers anywhere. I really enjoyed myself during those first few months. Later... (puffs)..." (Interview, Podemos/Ahora Madrid - city council)

"At that time there were no structures. We improvised everything. We had total access to social networks. Half the traffic of Loomio worldwide had to do with Podemos. It was a really special time" (Interview, Equo/Podemos/Ahora Madrid)

The up/down notions are related to the idea of going beyond the traditional boundaries of institutions. It is in this regard interesting to note that the democratic innovations seem to overflow the institutional party limits, and are always a source of frictions, despite all the efforts to incorporate them smoothly into the top decision-making levels. This idea is expressed by all interviewees, who stress the difference between the logic behind participation and party dynamics:

"Digital practices are seen by Ahora Madrid with some unease when it comes to ratifying processes; it is a matter of control ... the question of how these tools overflow does not follow the outline of party boundaries ... For example, regarding coalition agreements, some people look at these tools with utter horror ..." (Interview, Ahora Madrid)
"From a certain point, freedom of action was somewhat curtailed, perhaps because they feared the fragmentation of Podemos. It doesn't matter if the majority vote for basic income, because that cannot be defended on television. People lose trust and the group loses cohesion; internal conflict begins. The question was whether to open up participation further or to narrow it down. The fear. My stress ended with the emergence of Ahora Madrid." (Interview, Podemos/Ahora Madrid - city council)

"There was an inflection point ... a moment when we asked ourselves, are we Labodemo or Podemos? Disagreements soon emerged and things were left clear ... The debate was hot because Plaza Podemos could not be controlled. We pressed to make the decisions of Plaza Podemos binding for the party, to give it a strong role. Negotiations were hard. Finally the idea was accepted, but the quorum was so high ( $10 \%$ of all members) that it was impossible to reach. A mechanism of binding direct democracy was lost, a bit. And that's when we left Podemos. We started feeling like we were trying to hack Podemos. We tried to open it up, but we were too few. The negotiations were pretty stiff" (Interview, Equo/Podemos/Ahora Madrid)

Extension: Tech-activists believe that the scope of use of each tool can vary widely, from strictly instrumental uses to incorporation into the organization's strategy. In some cases, democratic innovations have only been assumed as a temporary complement, but for others they are organic elements which are central for the operation of the organization. This would seem to be the target, but it is still far from being achieved.

"There we wanted to valorize digital participation tools ... Everyone agreed that they were important, but no one was valorizing them. They were a shared value, a tool like environmentalism or feminism ... but there was no clear direction ... The process had to be started from scratch ... We had to awaken consciences." (Interview, Ahora Madrid)

In response to the instrumental, and tendentious, use that some were making of these tools, parallel organizations, which had technology at their core, soon emerged:

"Technology is Partido X's DNA ... Partido $X$ is unthinkable without technology. Zaragoza en Común and Podemos make a more instrumental use of technology. The old political parties use technologies because they have no option." (Interview, Partido X/ Zaragoza en Común)

The limitations to the scope of digital participation and online democratic innovations are part of the (generational) digital divide, which is also reflected in the conflict between social movement and party:

\footnotetext{
"At first nobody saw this as a problem ... when Ahora Madrid won and the process started getting bigger, the digital divide issue materialized again, the issue of legitimacy ... a conflict between using digital tools for democracy and the use of from the bottom up methods ... Some people felt threatened by this." (Interview, Ahora Madrid)
} 
"As a participation group, we filed a proposal, a small memo on the organization of Podemos and digital participation. We called it Iniciativas Ciudadanas Podemos, a space for suggestions and debate, where proposals could be submitted and voted (the vote was binding). This was approved; it was one of the things that the Citizen Council passed, but we had to fight hard for it." (Interview, Podemos/Ahora Madrid - city council) $)^{9}$

"There is a sector, [coming] from neighborhood associations, which is closed to society and to the digital media. Municipal movements want participation, but they come from a limited traditional approach. Some participation policies are out of date and out of touch with the internet, but they gain power easily." (Interview, Equo/Podemos/Ahora Madrid)

The forecast is that the movement will grow gradually but without limits, impregnating society with their own values.

"Digital activism or hacktivism existed before, but this has been a turning point. Now the whole of society knows about it. Before we were just a few nutters, but now we are many more. Now it has been proven to work, that it is instantaneous and that there is an ideology behind it. It has penetrated society through the social movements." (Interview, Partido X/Zaragoza en Común)

"Our activity is now focused not so much on changing the council but on extending this movement to other places. Beforehand, all the efforts were directed at getting people involved, but now we have moved on. Now it is not about starting constitutional processes. Now we are thinking how to change society through massive participation processes within the institutions" (Interview, Podemos/Ahora Madrid - city council)

"We are trying to reinforce this idea within Municipalism. Everywhere. But we still fall short in many things. We are lacking in books, intellectuals, strategies, discourses. We must prove that it can work, with examples like Madrid. We need this to be solid, and work in Madrid. It is a growing trend worldwide. We want to change politics that way" (Interview, Equo/Podemos/ Ahora Madrid)

Timing: Almost all interviewees trace back the origin of the current political cycle to $15 \mathrm{M}$. Although some earlier references also appear (including the Transition to democracy and Franco's Spain), 15M is the starting point for the new relationship between technological and political activism (Fuster 2012; Postill 2014; Monterde 2015). It is interesting to note that according to the activists' narratives, democratic innovation always comes from the field of social movements and unconventional collective action. The references to the origin of the indignados movement are frequent. From there, a chronological narrative unfolds in which the relationship of technology and politics over time is examined. It is as though a causal relation existed between the evolution of the new parties and the use that they make of digital participation tools. In the case of Ganemos this is particularly clear:
"Mailing lists were the continuation of assemblies and meetings ... Information was gathered online and suggestions were collected. This was turned into a map, mapa.ganemos.info; I am not sure if it is still up ... Later we continued giving support with a web, but it was not very interactive. The first example of digital participation was with regard to the issue of the political support, the ratification of the process." (Interview, Ahora Madrid)

In many cases, this mediated social action attracted members from other parties:

"What attracted me to Partido X was not so much the use it made of technology, but that the usual problems were solved through technology in a flexible way which was open to new ideas; it was pragmatic and open to collaboration, to distribute tasks, etc." (Interview, Partido X/Zaragoza en Común)

Podemos was perhaps the most precocious in showing how some of these tools were being incorporated, in response to both the general political context and the contributions of tech-activists, who also evolved: from putting together the first internal spaces for participation and debate (tools like Reddit, Loomio, etc.) to designing decision-making mechanisms (for example Iniciativas Ciudadanas Podemos).

Techno-political discourse/innovation frames: In some ways, the incorporation of the innovations proposed by social movements to institutions is mediated by a series of discourses and frames. The diffusion of these innovations relies on the prevalence of the right diagnostic and prognostic frames (Snow and Benford 1988). The interviewees agree that technological environments are an opportunity for activism, both within and outside institutions. Recent research suggests that there is nothing inherently democratic in digital communication technologies, because parties and governments often use allegedly emancipatory technologies in order to control activism (Morozov 2012; Treré 2016). Spanish activists, however, believe that the window of opportunity created by new technologies depends on the technical characteristics of the digital space, which remains open to citizen participation.

"The structure of the internet guarantees its neutrality; it is a paradigm of possibility for minorities." (Interview, Ahora Madrid)

"New technologies have played a crucial role in this process. Before, it was impossible to put a message across, get people together, converge, because the [traditional] media were controlled by economic groups." (Interview, Partido X/Zaragoza en Común)

This arrives at a merger of technical and political approaches:

"The use that one makes of technology cannot be disregarded from the style of politics we want to put forward." (Interview, Ahora Madrid) 
Politics and technology become so entangled that the form of organization of post-15M parties was almost software-like, as reflected in a recurrent metaphor:

"An organization is like a metaphor for a computer program, with different tasks, libraries, etc. A political party is like a pad, an example of or metaphor for collaborative organization ... Traditionally, processes were begun by a single person; now it is open to everyone; the regulations are written in common. It is a shift of political paradigm" (Interview, Partido X/ Zaragoza en Común)

In this way, technology was the channel of discontent, the magic pot that turned disillusionment into mobilization and faith:

"It was like magic; we took advantage of the moment ... a convergence of people, timing and place, and that something that was there, and... presto! The spark goes off ... but this can only happen if the situation is ripe ...there must be faith in technology, the wisdom to know that it is going to make it easier for those parties. You have to trust and use it with no fear." (Interview, Partido X/Zaragoza en Común)

This ushers in a new time, the time of new politics inaugurated by $15 \mathrm{M}$ and continued by the new parties (Ardanuy and Labuske 2015: 96). ${ }^{10}$ We might say that this is the identity frame (or the identity component of the collective action frame [Gamson 1992]) along with the prognosis, because only one way is left open for political action.

"Technologies had an influence on $15 \mathrm{M}$, they were key for its success, the dissemination of new politics ... Old politics, new politics and new technologies run parallel. There is a relationship; that it is a causal relationship, I wouldn't dare to say; but there is mutual influence, a circular causality." (Interview, Partido X/ Zaragoza en Común)

"15M could not have happened without tech-activists ... The percentage of people in the square who came from that techno-political world was very high. There was a moment when hackers started inhabiting self-managed spaces, and that created new possibilities for activism." (Interview, Podemos/Ahora Madrid-city council)

"At that time I joined Equo; I wanted to move on from street protest and get closer to positions of power. I started looking for new ways to do things. There were annoying habits that reminded you of the old style, the way meetings were handled; there was no openness, no transparency etc. I did not want people who were a minority to win decisions by sheer saturation. We all had the impression that we needed digital tools ... There were many things that needed changing and we started seeking ways to do it. We realized that this could make a real difference, going beyond traditional dynamics of left-wing parties." (Interview, Equo/Podemos/Ahora Madrid)

The general forecast is that an era has started in which digital participation mechanisms and the associated democratic innovations will add value to politics (cf. Treré 2016).
"The digital participation processes that have been set in motion are not as big as we would've wanted, but they do follow the idea of doing things collaboratively, all citizens together ... Even the voting and counting systems in the primary elections is not capricious, but responds to the wish to give minorities a voice without upsetting the proportionality principle. It is the best system to date." (Interview, Ahora Madrid)

"Technology makes it possible to collaborate with no time constraints, in a much more social way. It foments more extensive and profound forms of collaboration. Without new technologies our relationship is limited to when we see each other. We can attain a deeper and wider relationship through technology, because it's not necessary for us to be together in the same place" (Interview, Partido X/Zaragoza en Común)

"Participation always means taking away power from those who have it. Real participation is taking power away from representatives. And not all of them are willing to let it go. Even within Municipalism. Binding participation processes must be introduced; a distributed process must decide what to do, not a representative. That's the challenge." (Interview, Equo/ Podemos/Ahora Madrid)

In some cases, appeals are made to so-called "collective intelligence," (or "collective thought") one of the key values in the concept of deliberative democracy put forth by $15 \mathrm{M}$ (Romanos 2011), and which, in the opinion of tech-activists, is the reason behind the power of recent democratic innovations:

\begin{abstract}
"Collective intelligence is beyond consensus; it is not a matter of agreeing but of putting as many ideas together as possible and doing something with them so they can succeed. It is neither immediate nor easy. We have to develop ways to make this work. The people will decide which ideas are worth pursuing." (Interview, Podemos/Ahora Madrid)
\end{abstract}

\section{Discussion AND CONCLUSIONS}

In this article we have tried to analyze the notion of "democratic innovation" on the basis of a case study: the role played in Spain by grassroots tech-activism in the post-15M cycle and its involvement in the new political parties thereof. A dialogue with the theories which focus on new forms of political participation has also been attempted. So-called "latent participation" forms (Amnå and Ekman 2014) nurtured by social movements become sort of "democratic innovations" (Talpin 2015) when a favorable sociopolitical context and other environmental conditions exist, specifically the opportunity for tech activists to work as external collaborators with parties and city councils that trust in the democratic potential of political mobilization from above. Some of the 15M tech-activists collaborated with new political parties and institutions, facilitating the transition of practices and political cultures, though this was not without resistance. These activists, therefore, acted as "bridges" (Heaney and Rojas 
2014), helping the penetration of the democratic innovations described by Talpin (2015) into the political parties and the institutions.

This article has focused on innovations based on digital participation and on how tech-activists tried to adapt their participation devices to the emerging political parties. Research on the implementation of democratic innovation in political institutions as demanded by the anti-globalization movement demonstrates that the organization of civil society groups and organizations can affect their strategies and action repertoires: The more participative they are, the less willing they are to cooperate with state institutions, also in connection with democratic innovations (Talpin 2015). Similarly, the larger and more professionalized they are, the harder it will be for them to interact with institutions. Our research broadens the focus even further and incorporates other factors that also help to explain the adoption of democratic innovations by political institutions. Experts in ICTs who had taken part in $15 \mathrm{M}$ and who joined some of the emerging parties and electoral coalitions tried to bring with them new online participation formats and deliberative digital devices. However, the adoption of these mechanisms by new parties was not automatic, but depended on a series of variables. We have tried to examine the discourse of these activists in order to determine the meanings and dimensions behind these democratic innovations, namely: the status of these activists with regard to the party (outside/inside); the scope of innovations (instrumental/structural); duration (short term for unconventional collective action/pace of operation of parties and institutions); the control of democratic innovations (from a movement's horizontalism to certain party hierarchy); and finally the diagnostic and prognostic frames associated to techno-politics (which distinguish between the new and the old).

The analysis of the interviews can be used to draw a synthetic map of the characteristics of the democratic innovations and participative models introduced by the tech-activists. Specifically, we are interested in some of the factors highlighted by the interviewees, which are revealing in terms of the way in which these processes transition between social movements and institutions.
Based on this, our conclusion is that some of the innovations that emerged from the Spanish social movements associated with $15 \mathrm{M}$ were assumed by the new political parties when certain conditions converged. These factors determined the tech-activists' perception of their own role and the way they interacted with the environment. We are largely referring to innovations related to debate, deliberation and decision-making tools (Appgree, Loomio, Reddit, etc.). The incorporation of these devices into the operation of political parties depends on the position occupied by tech-activists within the parties, the control mechanisms implemented by the parties, the duration and timing of the relationship between the tools and the party, the willingness to extend deliberative experiments, and the associated interpretative frames.

However, one should avoid thinking that technological activists can generate democratic innovations automatically or easily. Our analysis shows the conditions of reception and interaction between social movements and political parties to be very relevant in this regard. The degree of authoritarianism and hierarchical rigidity of the political parties with which the movements interact is important, in addition to their electoral expectations and level of consolidation and institutionalization. Indeed, Podemos and Ahora Madrid showed a different level of interest and receptiveness to the proposals put forward by technological activists: more instrumental and limited in the former while more structural and broad in the latter, as indicated by the activists interviewed. Other contextual variables should be considered such as the political opportunity structure or the different types of institutional governance. Let us bear in mind that opportunities in this case do not only apply to the emergence of unconventional forms of collective action, but also to the generation of alliances and the transcending of institutional spaces. In this sense, the mixture of political opportunity and governance style could be referred to as democratic innovation opportunities structure.

The kind of tech-activism that it is being dealt with and how it is interwoven with social movements should also be considered. As a matter of fact, democratic innovations are not evenly adopted across the board, and a progressive, step-by-step

\begin{tabular}{|l|c|c|}
\hline & \multicolumn{2}{|c|}{ Democratic innovations (digital participation) } \\
\hline Status (position of tech-activists) & Exterior (temporary collaboration) & Interior (membership) \\
\hline Control (of tech-activism) & Up>down (managed from the organization) & $\begin{array}{c}\text { Down>Up (open and managed by the } \\
\text { people themselves) }\end{array}$ \\
\hline Duration/Timing & Short term & Long term \\
\hline Scope & Limited, instrumental, tendentious, contained & Non-limited, structural, overflowing \\
\hline Techno-political/ Frame & Old politics & New politics \\
\hline
\end{tabular}


model could be developed. We can apply Mergel and Bretschneider's (2013) model concerning the adoption of the social media by the administration, which establishes three different stages: i) informal experimentation, ii) first regulation and adoption and iii) formalized social media strategies and policies. We may say that most social movements are situated at the level of informal experimentation, but $15 \mathrm{M}$ tech-activists have been able to reach the two upper levels. The adoption process of democratic and digital innovations relies on the action of entrepreneurs (tech-activists) to carry it through the different stages in order to evolve from decentralized, informal and early experimentation to the institutionalization and consolidation of digital participation.

The participation and deliberation tools used by new parties in Spain seek a stronger involvement of the public in horizontal and democratic processes (Romanos and Sádaba 2015). Even if statistically it is not always clear that the parties' supporters and the general public are using these tools extensively, they always appear prominently in the public discourse. For example, the so-called "Ayuntamientos por el cambio" (Councils for Change, i.e. councils in the hands of post-15M parties) have specific offices for participation, transparency and open government. Those in charge of these areas regard new technologies as an integral part of the institutional structure, which generates resources and promotes democratic participation and deliberation. In doing so, they may reproduce "an ideological orientation" which Gerbaudo (2014) has labeled "Populism 2.0". The principles of interactivity, openness and directness which dominate the "ideology of social media" are thus transferred to the political arena, where the new political parties, and their use of new digital tools, present themselves as the solution to the public demand for transparency, accountability and proximity, which

\section{ACKNOWLedgments}

This article is part of the project CSO201341035-P, funded by the Spanish Ministry of Economy and Competitiveness. We would like to thank the interviewees and participants in BetaDemIC project for sharing their experiences and thoughts with us. have been disregarded by the traditional parties. Recent case studies have analyzed the relationship between this kind of parties - i.e. recently created parties with a similar outlook on new technologies and digital technologies in other countries. They have demonstrated that the theory and the practice - the myth of digital democracy and the real effects of the use of these, allegedly liberating, technologies - do not always go together. A good example is the 5 Star Movement of comedian-turned-politician Beppe Grillo in Italy. Treré and Barassi (2015: 287) have claimed that "the digital rhetoric of horizontality, lack of leadership, and spontaneity of the party is used to mask, facilitate and reinforce the authority of Beppe Grillo as a political leader, thus forging a new type of authoritarianism that is supported and legitimated through the everyday construction of digital discourse."

In this sense, further research can focus on the evolution of 15M's "democratic innovations". The digital participation mechanisms promoted by techactivists and implemented by the new parties under the motto "The people will decide" might also have unexpected, and not always desirable or democratic, consequences. The focus on the procedures tends to forget and blur the social conditions under which technological participation led to legitimate democratic transformations. The intensive participation of tech-activists in the construction of the digital structures which sustain participation- and deliberationfostering democratic innovations may stand as a barrier against authoritarian tendencies in the Spanish case. These activists not only pose democratic demands of the new parties and institutions, but are also acting as a kind of safety net for democratic innovations, counteracting ("hacking") attempts at directing democratic processes by those who have more power within parties and institutions. We shall see who wins this struggle.

\section{Notes}

1. Underlying this culture there is a strong sense of prefiguration, understood as a strategy for social change based on the consistency between means and ends. This is, once again, linked to Anarchism. Although considered by some an invention of the 1968 protests, prefiguration features in Anarchist theory from an early stage: Bakunin and his followers forecasted the arrival of a future society, the "embryo" of which must be the Workers' International. Anarchist constructive projects created in parallel to workers' associationism, related to education, culture and information, also prefigure a model of the antiauthoritarian, free and nonhierarchized social model pursued by its organizations, groups and activists (Romanos 2013).

2. Indeed, "PPSOE" and "PSOE, PP, la misma mierda es" [PSOE, PP, they are the same shit] were among the most popular slogans in the anti-austerity protests (Basteiro 2013). 
3. "Council platforms" [plataformas municipalistas] refer to the electoral coalitions arising out of the confluence of Podemos with other parties - some newer (e.g. Ganemos) than others (e.g. Equo) - which took part in 2015 local elections.

4. https://decide.madrid.es/

5. http://medialab-prado.es/article/herramientas-parala-democracia

6. The metaphor "up-down" and "down-up" is used constantly: "they are new parties, they come from the bottom up ... not from the top down ... A few years ago everyone was against political parties, and now everyone belongs to one. At least in Zaragoza. But I see no contradiction in this. I think it is logical and consistent. People were not against politics, but against those parties ... Now we have emerging parties, because they are coming from the bottom up" (Interview, Partido X/Zaragoza en Común).

7. LaboDemo (Laboratorio Democrático) is a small group of tech-activists which started cooperating with Podemos (in fact, it was the main element in the party's Participation Area). Later, some of its members (individually, no longer as a group) started working with Ahora Madrid, both from within the public institutions (council offices of Citizen

\section{References}

Amnå E. and J. Ekman, J. 2014. "Standby citizens: diverse faces of political passivity", European Political Science Review 6(2): 261-281.

Anduiza, E., A. Gallego and M. Cantijoch. 2010. "Online political participation in Spain: the impact of traditional and Internet resources", Journal of Information, Technology \& Politics 7(4): 356-68. http://dx.doi.org/10.1080/19331681003791891

Ardanuy, M. and E. Labuske. 2015. "El músculo deliberativo del algoritmo democrático: Podemos y la participación ciudadana", Teknokultura 12(1): 93-109. http://dx.doi.org/10.5209/rev_tk.2015.v12.n1.48887

Arribas, A. 2015. "Recordar el 15M para reimaginar el presente: Los movimientos sociales más allá del ciclo electoral de 2015", Interface 7(1): 150-64.

Asens, J. 2004. "La presión al movimiento de las okupaciones: del apartato policial a los mass media." Pp. 293-338 in ¿Dónde Están las Llamas? El Movimiento Okupa: Prácticas y Contextos Sociales, edited by In R. Adell and M. Martínez. Madrid: Los Libros de la Catarata.

Basteiro, D. 2013. "García-Page: Tenemos que acabar con el lema del 15M "PSOE y PP, la misma mierda es", El Huffington Post, 7 November. Available at http://www. huffingtonpost.es/2013/11/07/garcia-page-entrevistapsoe-15m_n_4226942.html

Bennett, W.L., C. Breunig and T. Givens. 2008. "Communication and political mobilization: Digital media and the organization of anti-Iraq war demonstrations in the US", Political Communication 25(3): 269-89. http://dx.doi.org/10.1080/10584600802197434

Brinkmann, S. and S. Kvale. 2014. InterViews: Learning the Craft of Qualitative Research Interviewing. London: Sage. http://dx.doi.org/10.1007/978-1-4614-5583-7_161

Buss, T.F., F.S. Redburn and K. Guo. 2007. Modernizing Democracy: Innovations in Citizen Participation Innovations in Citizen Participation. London: Routledge.

Calderaro, A. and A. Kavada. eds. 2013. Policy and Internet 5(1), Special Issue: "Online collective action and policy change".

Chi, E., S. Munson, G. Fisher, S. Vieweg and C. Parr. 2010. "Advancing the design of technology-mediated social participation systems", IEEE Computer, November.
Participation, Transparency and Open Government) and from outside (for example, the aforementioned project BetaDemIC). According to the group's website: "Our aim is to open institutions and organizations in order to create a more participative and democratic world. We work towards a super-connected new society, towards the creation of new forms of networked collective intelligence. In order to achieve this, we design online participation strategies, as well as new tools with which to enlarge the boundaries of this notion." (http://labodemo.net/es/)

8. The Citizen Council is the political decision-making organ in Podemos. https://transparencia.podemos.info/ cargos-internos/

9. For Iniciativas Ciudadanas Podemos see https://participa.podemos.info/es/propuestas/info

10. The references to the old politics and the old social movements are almost humoristic in tone: "There is no drastic change; each medium has its language and its impact, emails, text messages, blogs, social networks, whatsapp, Twitter... Each is quicker than the next ... If it wasn't for technology, we'd still be distributing photocopied pamphlets (laughs)." (Interview, Partido X/ Zaragoza en Común)

Corsín, A. and A. Estalella. 2011. "\#spanishrevolution", Anthropology Today 27(4): 19-23.

Dahlberg, L. and E. Siapera. 2007. Radical democracy and the Internet: interrogating theory and practice. Palgrave Macmillan. http://dx.doi.org/10.1057/9780230592469

della Porta, D. 2005a. "Deliberation in Movement: Why and How to Study Deliberative Democracy and Social Movements", Acta Politica 40: 336-50. http://dx.doi. org/10.1057/palgrave.ap.5500116

della Porta, D. 2005b. "Making the Polis: Social Forums and Democracy in the Global Justice Movement", Mobilization 10(1): 73-94.

della Porta, D. 2014. Mobilizing for Democracy. Oxford: Oxford University Press. h t t p://dx.doi.org/10.1093/acprof:o so/9780199689323.001.0001

della Porta, D. and M. Diani. 2006. Social Movements: An Introduction (2nd ed.). Malden: Blackwell.

della Porta, D., M. Andretta, T. Fernandes, F. O'Connor, E. Romanos and M. Vogiatzoglou. 2016. Late neoliberalism and its discontent: Comparing crises and movements in the European periphery. Palgrave (forthcoming).

Denzin, N. and Y. Lincon. 2005. The SAGE Handbook of Qualitative Research. London: Sage.

Earl, J. and K. Kimport. 2011. Digitally Enabled Social Change: Activism in the Internet Age. London: MIT Press. h t t p : / / d x . d o i. or g/10.7551/ m i t press/9780262015103.001.0001

Ekman, J. and E. Amnå. 2009. "Political participation and civic engagement: towards a new typology", Human Affairs 22: $283-300$

Espinoza Pino, M. 2013. "Politics of indignation: Radical democracy and class struggle beyond postmodernity", Rethinking Marxism 25(2): 228-41. http://dx.doi.org/10.1080/08935696.2013.769358

Fernandes, T. 2014. "Rethinking pathways to democracy: civil society in Portugal and Spain, 1960s-2000s", Democratization 37 : 1-31. 
Fishman, R.M. 2011. "Democratic Practice after the Revolution: The Case of Portugal and Beyond", Politics \& Society 39(2): 233-67. http://dx.doi.org/10.1177/0032329211405439

Flesher Fominaya, C. 2014a. Social Movements and Globalization: How Protests, Occupations and Uprisings are Changing the World. New York: Palgrave Macmillan.

Flesher Fominaya, C. 2014b. "Spain is Different: Podemos and 15-M", openDemocracy, 29 May. Available at https://www.opendemocracy.net/can-europe-make-it/ cristina-flesher-fominaya/"spain-is-different"-podemosand $-15 m$

Font, J. and P. Alarcón. 2012. “¿Cómo queremos que se tomen las decisiones políticas", Zoom Político 2.

Font, J., J. Clemente, M. Wojcieszak and P. Alarcón. 2012. ¿'Democracia sigilosa' en España? Preferencias de la ciudadanía espa-ola sobre las formas de decisión política y sus factores explicativos. Madrid: CIS.

Fuster, M. 2012. "The Free Culture and 15M Movements in Spain: Composition, Social Networks and Synergies", Social Movement Studies 11(3-4): 386-92 http://dx.doi.org/10.1080/14742837.2012.710323

Gamson, W.A. 1992. Talking Politics. Cambridge: Cambridge University Press.

Ganuza, E. and G. Baiocchi. 2012. "The Power of Ambiguity: How Participatory Budgeting Travels the Globe", Journal of Public Deliberation 8(2).

Gerbaudo, P. 2014. "Populism 2.0: Social media activism, the generic Internet user and interactive direct democracy." Unpublished paper.

Gimmler, A. 2001. "Deliberative Democracy, the Public Sphere and the Internet", Philosophy and Social Criticism 27(4): 21-39. http://dx.doi.org/10.1177/019145370102700402

Gunther, R., J.R. Montero and J. Botella. 2004. Democracy in Modern Spain. New Haven, CT: Yale University Press.

Heaney, M. and F. Rojas. 2015. Party in the Street: The Antiwar Movement and the Democratic Party after 9/11. Cambridge: Cambridge University Press. http://dx.doi.org/10.1017/CBO9781316084007

Heaney, M.T. 2013. "Elections and Social Movements". Pp. 391-94 in The Wiley-Blackwell Encyclopedia of Social and Political Movements, edited by D.A. Snow, D. della Porta, B. Klandermans and D. McAdam. Malden: Wiley-Blackwell. http://dx.doi.org/10.1002/9780470674871.wbespm078

Hintz, A. and S. Milan. 2009. "At the margins of Internet governance: grassroots tech groups and communication policy", International Journal of Media and Cultural Politics 5(1\&2): 23-38. http://dx.doi.org/10.1386/macp.5.1-2.23_1

Jerez, A., S.D. Maceiras and E. Maestu. 2015. "Esferas públicas, crisis política e internet: el surgimiento electoral de Podemos", História, Ciências, Saúde - Manguinhos 22 (suppl.): 1573-96.

Jiménez, M. 2007. "Mobilizations against the Iraq War in Spain: Background, Participants and Electoral Implications", South European Society \& Politics 12(3): 399-420. http://dx.doi.org/10.1080/13608740701495392

Kitschelt, H. 1993. "Social Movements, Political Parties, and Democratic Theory", Annals of the American Academy of Political and Social Sciences 528: 13-29. http://dx.doi.org/10.1177/0002716293528001002

Kriesi, H. and D. Wisler 1999. "The Impact of Social Movements on Political Institutions: A Comparison of the Introduction of Direct Legislation in Switzerland and the
United States". Pp. 42-65 in How Social Movements Matter, edited by M. Giugni, D. McAdam and C. Tilly. Minneapolis: Minnesota University Press.

Likki, T. 2012. "15M Revisited: A Diverse Movement United for Change", Zoom Politico 11

Lobera, J. 2015. "De movimientos a partidos. La cristalización electoral de la protesta", Revista Española de Sociología 24: 97-105.

Marzolf, H. and E. Ganuza. 2016. “¿Enemigos o colegas? El 15M y la hipótesis Podemos", Empiria 33: 89-110. http://dx.doi.org/10.5944/empiria.33.2016.15865

Mason, M. 2010. "Sample Size and Saturation in PhD Studies Using Qualitative Interviews", Forum Qualitative Sozialforschung / Forum: Qualitative Social Research 11(3): art. 8. Available at http://nbn-resolving.de/ urn:nbn:de:0114-fqs100387.

Mergel, I. and S.I. Bretschneider. 2013. "A Three-Stage Adoption Process for Social Media Use in Government", Public Administration Review 73(3): 390-400. http://dx.doi.org/10.1111/puar.12021

Monterde, A. 2015. Emergencia, evolución y efectos del movimiento-red 15M (2011-2015). Una aproximación tecnopolítica. Tesis doctoral, UOC.

Mora, F.A. 2014. "Emergent Digital Activism: The Generational/Technological Connection", The Journal of Community Informatics 10(1).

Morozov, E. 2012. The Net Delusion: The Dark Side of Internet Freedom. New York: Public Affairs.

Newton, K. and B. Geissel. 2011. Evaluating Democratic Innovations: Curing the Democratic Malaise? London: Routledge.

Polletta, F. 2002. Freedom is an Endless Meeting. Democracy in American Social Movements. Chicago: The University Press of Chicago. h t t p : / / d x.doi.org/10.7208/ch i c ago/9780226924281.001.0001

Postill, J. 2014. "Freedom technologists and the new protest movements: A theory of protest formulas", Convergence 20(4): 402-18. http://dx.doi.org/10.1177/1354856514541350

Redes, Movimientos y Tecnopolítica. 2014. \#Encuesta15M2014 [Fichero de datos]. Barcelona: IN3, Universitat Oberta de Catalunya. Available at http://civilsc. net/encuesta15m2014_datos.

Roberts, K. 2014. "Populism, Social Movements, and Popular Subjectivity". Pp. 681-95 in Oxford Handbook on Social Movements, edited by D. della Porta and M. Diani. Oxford: Oxford University Press.

Romanos, E. 2011. "El 15M y la democracia de los movimientos sociales", Books and Ideas, 18 October.

Romanos, E. 2013. "Collective Learning Processes within Social Movements: Some Insights into the Spanish 15M Movement". Pp. 203-19 in Understanding European Movements, edited by Laurence Cox and Cristina Flesher Fominaya. London: Routledge.

Romanos, E. 2016. "Immigrants as Brokers: Dialogical Diffusion from the Spanish Indignados to Occupy Wall Street", Social Movement Studies 15(3): 247-262. http://dx.doi.org/10.1080/14742837.2015.1095084

Romanos, E. and I. Sádaba. 2015. "La evolución de los marcos (tecno)discursivos del movimiento $15 \mathrm{M}$ y sus consecuencias", Empiria 32 : 15-36. http://dx.doi.org/10.5944/empiria.32.2015.15307

Sampedro, V. 1997. "The Media Politics of Social Protest", Mobilization 2(2): 185-205. 
Sintomer, Y., C. Herzberg and A. Röcke. 2008. "Participatory Budgeting in Europe: Potentials and Challenges", International Journal of Urban and Regional Research 32(1): 164-78. http://dx.doi.org/10.1111/j.1468-2427.2008.00777.x

Smith, G. 2009. Democratic Innovations: Designing Institutions for Citizen Participation. Cambridge: Cambridge University Press. http://dx.doi.org/10.1017/CBO9780511609848

Snow, D.A. and R.D. Benford. 1988. "Ideology, frame resonance, and participant mobilization", International Social Movement Research 1: 197-217.

Talpin, J. 2015. "Democratic Innovation". Pp. 781-92 in The Oxford Handbook of Social Movements, edited by Donatella della Porta and Mario Diani. Oxford: Oxford University Press.

Tarrow, S. 2011. Power in movement: Social Movements and Contentious Politics (3rd ed.). Cambridge: Cambridge University Press. http://dx.doi.org/10.1017/CBO9780511973529

Tilly, Ch. 2004. Social Movements, 1768-2004. Boulder: Paradigm.

Towsend, A. 2013. Smart Cities: Big Data, Civic Hackers, and the Quest for a New Utopia. New York: Norton \& Company.

EDUARDO ROMANOS is currently working as a Ramón y Cajal Fellow in the Department of Sociology I (Social Change) at the Universidad Complutense de Madrid, Spain. He has previously worked as a postdoctoral fellow at the University of Trento, Italy, and as a Juan de la Cierva Fellow at the Universidad Pública de Navarra, Spain. Eduardo received his PhD in Political and Social Sciences from the European University Institute in Florence, and also holds a European Doctorate Certificate in Social History following a Marie Curie Fellow position at the University of Groningen, The Netherlands. Among his most recent publications are articles in Journal of Historical Sociology, Revista Española de Investigaciones Sociológicas, Revista Internacional de Sociología, Contemporary European History, and Social Movement Studies. His main research interests are in the areas of political sociology and historical sociology, with a particular focus on social movements and protest. Eduardo is currently conducting research on the Spanish indignados and the new transnational wave of contention. His previous research project focused on the anarchist movement in postwar Spain and Europe. Between 2013-2015, he acted as coordinator of the Research Network on Social Movements (RN25) of the European Sociological Association (ESA).
Treré, E. 2016. “The Dark Side of Digital Politics: Understanding the Algorithmic Manufacturing of Consent and the Hindering of Online Dissidence", IDS Bulletin 47(1): 127-38. http://dx.doi.org/10.19088/1968-2016.111

Treré, E. and V. Barassi. 2015. "Net-Authoritarianism? How Web Ideologies reinforce Political Hierarchies in the Italian '5 Star Movement', Italian Journal of Cinema and Media Studies 3(3): 287-304. http://dx.doi.org/10.1386/jicms.3.3.287_1

Van Laer, J. and P. Van Aelst. 2010. "Internet and Social Movement Action Repertoires", Information, Communication \& Society 13(8): 1146-71. http://dx.doi.org/10.1080/13691181003628307

Vissers, S. and D. Stolle. 2013. "How do I change politics? Evaluating the effectiveness of political participation modes". Paper prepared for the Annual Meeting of the Canadian Political Science Association.

Witschge, T. 2004. "Online Deliberation: Possibilities of the Internet for Deliberative Democracy". Pp. 109-22 in Democracy Online: the Prospects for Political Renewal through the Internet, edited by P.M. Shane. London: Routledge.

Wodak, R. and M. Meyer. 2009. Methods of Critical Discourse Analysis. London: Sage.

IGOR SÁDABA holds a degree in Physics (1996) and Sociology (2001), a postgraduate course in Critical Theory (2003) and also a PhD in Sociology (2007) from Complutense University of Madrid. He has been Lecturer at the Sociology and Political Science Department (Carlos III University of Madrid). Currently he is Associate Professor at the Department of Sociology IV in the Complutense University of Madrid. Among his most recent publications are various chapters, articles and reviews in Spanish and international journals and the books Intellectual Property ¿ private goods or public goods? (La Catarata, 2008), Social Movements and digital culture (ed. with Angel Gordo) (La Catarata, 2008), Open domain: free knowledge and cooperation (Circulo de Bellas Artes, 2009), Cyborg (Peninsula, 2009) and Social Research Methodology: Innovations and Applications (ed. with Millan Arroyo, 2012). His research interests are in the areas of new technologies, social movements, social exclusion and economic sociology. He has conducted research on social and political impact of new technologies, digital divide and inequalities, intellectual property and innovation, prisons and social research methods. He is member of the Research Group UCM Digital Culture and Social Movements (Cibersomosaguas) and TRANSOC Institute. 